\title{
A NOTE ABOUT NEW AND RARELY RECORDED TAXA OF THE GENUS CLADONIA FROM THE ARCTIC ISLAND SPITSBERGEN (SVALBARD)
}

\author{
PIOTR OSYCZKA \\ Department of Polar Research and Documentation \\ Institute of Botany, Jagiellonian University \\ Kopernika 27, 31-501 Kraków, Poland \\ e-mail: osyczka@ib.uj.edu.pl
}

(Received: December 6, 2004. Accepted: January 25, 2005)

\begin{abstract}
The paper is based on field studies dealing with the lichen genus Cladonia Hill ex P. Browne (Cladoniaceae) carried out by the author in the region of Spitsbergen in 2002 as well as taxonomical work and revision of herbarium material, collected during several earlier Polish polar expeditions to this part of the Arctic. As the result not reported so far from the island species Cladonia stygia (Fr.) Ruoss, C. trassii Ahti, C. verticillata (Hoffm.) Schaer. have been determined. Besides, the presence of very rarely recorded taxa C. crispata var. cetrariiformis (Delise) Vain., C. merochlorophaea Asahina and Cladonia symphycarpia (Flörke) Fr. is confirmed and their new localities are given. Furthermore, the presence of $C$. coccifera s.str. is also substantiated.
\end{abstract}

KEY WORDS: the Arctic, Svalbard, Spitsbergen, Cladonia, lichenized fungi, lichens, taxonomy, distribution.

\section{INTRODUCTION}

Svalbard $\left(74^{\circ}-81^{\circ} \mathrm{N}\right.$ and $\left.10^{\circ}-35^{\circ} \mathrm{E}\right)$ is the group of arctic islands situated almost midway between Greenland and Novaya Zemlya. It consists of five large islands: Spitsbergen, North-East Land (Nordaustlandet), Edge Island (Edgeøya), Barents Island (Barentsøya) and Prince Charles Foreland (Prins Karls Forland) and approximately 150 small islands and islets divided by straits from the main group. The largest island is Spitsbergen. Nearly $60 \%$ of the land area of Svalbard is covered by glaciers (Hisdal 1985) and in the remaining polar desert and tundra areas bryophytes and lichens often play a dominant role. Actually, almost 600 lichen species are known for this region (Elvebakk and Hertel 1996).

Species of the genus Cladonia Hill ex P. Browne are widespread on Svalbard, being significant components of the arctic tundra. Almost 40 species of the Cladonia were recorded so far. The genus in this part of the Arctic, besides the lichen genera Caloplaca and Rhizocarpon, is one of the richest in species (Elvebakk and Hertel 1996). Some representatives of the genus, such as: Cladonia amaurocraea (Flörke) Schaer., C. borealis S. Stenroos, C. macroceras (Delise) Hav., C. mitis Sandst. (=C. arbuscula ssp. mitis (Sandst.) Ruoss), C. pocillum (Ach.) Grognot, C. pyxidata (L.) Hoffm., C. rangiferina (L.) F.H. Wigg., are common on Svalbard. Some other taxa have been reported only from single or few localities. This could either be explained by the lack of sufficient data about their occurrence or real rarity of these taxa in the region. It should be noted that representatives of the genus Cladonia are often strongly modified by the severe climate conditions, i.e. long periods of freezing temperatures, snow cover, strong wind, ice and mineral particle abrasion.

\section{MATERIALS AND METHODS}

Field investigations were carried out by the author during the summer of 2002 and covered several areas of west coast of Spitsbergen: Hornsund, Bellsund, Adventfjorden (Isfjorden), Petuniabukta (Billefjorden) and Kaffiøyra (Oscar II Land). Field research comprised various habitats located on plains of raised marine terraces, on nival moraine ridges, in valley of pronival and proglacial streams, on storm ridges, at bottoms and on slopes of mountain massifs. In addition, specimens belonging to the genus Cladonia collected during earlier Polish polar expeditions were determined or verified. These herbarium materials were mainly gathered by M. Olech from Sørkapp Land, Hornsund and Grønfjorden (Isfjorden), by W. Gugnacka-Fiedor from Kaffiøyra (Oscar II Land) and by F. Święs from Bellsund. 
The taxa were identified using methods of classical taxonomy supported by determination of lichen substances. Chemical analyses were done using thin-layer chromatography (TLC) technique according to standardized methods and procedures (Culberson and Kristinsson 1970; White and James 1985; Orange et al. 2001). Majority of examined specimens has been deposited in lichenological herbarium of the Institute of Botany of the Polish Academy of Sciences in Kraków (KRAM-L). Some small collections are present also in herbarium of the Nicolaus Copernicus University in Torun (TRN) and herbarium of the Botanical Museum of the University of Helsinki $(\mathrm{H})$.

\section{RESULTS AND DISCUSSION}

Cladonia stygia (Fr.) Ruoss (Fig. 1A)

Bot. Helv. 95: 241 (1985).

The general range of this species extends from the arctic zone across the boreal to temperate zone as well (Ahti and Hyvönen 1985). It is a frequent but often overlooked species. The species is considered to be closely related to $C$. rangiferina due to similar chemistry, morphology and DNA sequences (Ruoss and Ahti 1989; Brodo et al. 2001; Stenroos et al. 2002). These two species are often found associated or mixed together. Unlike $C$. rangiferina, however, $C$. stygia has the surface and stereome at the base of the thallus dark brown to black and contains red or pinkish slime in the conidiomata (Ahti and Hyvönen 1985; Brodo et al. 2001). C. stygia was found on a plain of raised marine terrace. It had overgrown a peaty substratum being accompanied with $C$. rangiferina and the moss Racomitrium lanuginosum (Hedw.) Brid. It is worth notice, that $C$. stygia seems to be considerably rarer than frequently occurring $C$. rangiferina. Earlier, $C$. stygia was recorded at Bjørnøya, which is remote to the south from Spitsbergen (Ahti and Hyvönen 1985).

Specimens examined. Spitsbergen: Hornsund, NE part of Kvartsittsletta, near the bottom of Ceglatoppen, 35 m, July 2002, P. Osyczka 334 (H; KRA); Hornsund, S part of Kvartsittsletta, 15 m, July 2002, P. Osyczka 335 (H; KRA).

\section{Cladonia trassii Ahti (Fig. 1B)}

Folia Cryptog. Estonica 32: 7 (1998).

After revision of Cladonia stricta (Nyl.) Nyl. (Ahti 1998) this taxon was divided into three species: $C$. stricta s. str., C. trassii Ahti, and C. uliginosa (Ahti) Ahti. All three species are typically arctic to subarctic and circumpolar. However, their precise ranges are still poorly known. Localities of $C$. trassii were ascertained in many regions and various habitats of western coast of Spitsbergen. Surely, it is a widespread lichen in the whole region of Svalbard. $C$. trassii was often found in the communities dominated by Racomitrium lanuginosum, Deschampsia alpina (L.) Roem. \& Schult. or Festuca vivipara (L.) Smith. Cladonia stricta, a similar arctic-alpine species, has an evanescent primary thallus, pointed or narrowly cupped podetia (often with perforated cups), with only few or a few podetial squamules and frequently does not contain atranorin (Ahti 1998; Brodo et al. 2001). Cladonia stricta s.str. was also found on Spitsbergen but it appears to be considerably rare (Osyczka 2003). Earlier, C. stricta was reported in this region by many authors (Elvebakk and Hertel 1996). Howe- ver, all these reports should to be treated as $C$. stricta s.lat. and they apparently mostly refer to $C$. trassii. For instance, the plate presented a distibution map of ' $\mathrm{C}$. lepidota var. stricta' in Svalbard region published by Lynge (1938) assuredly must be essentially a map of $C$. trassii.

Selected specimens examined. Spitsbergen: Sørkapp Land, storm ridge between Suffolkpynten and Raksodden, 8 m, August 1985, M. Olech (KRA); Sørkapp Land, Kulmstranda, near the Lisbetelva stream, 40 m, August 1985, M. Olech (KRA); Sørkapp Land, Hohenloheskardet pass, 75 m, July 1985, M. Olech (KRA); Hornsund, NE part of Kvartsittsletta, marine terrace between Bratteggdalen and Wrocławvika, 25 m, July 2002, P. Osyczka 283 (KRA); Hornsund, Bratteggdalen, W bank of Myrktjörn lake, the bottom of Gulliksenfjellet, 100 m, July 2002, P. Osyczka 286 (KRA); Hornsund, Angellfjellet, rocky cliffs of NW slope, 220 m, July 2002, P. Osyczka 287 (H; KRA); Hornsund, valley of the Revvelva stream, 30 m, July 2002 , P. Osyczka 282 (H; KRA); Bellsund, SW part of Lognedalen, towards $\mathrm{N}$ from the Logna River, $70 \mathrm{~m}$, August 1988, F. Święs 2514 (H; KRA); Bellsund, NW part of Lognedalen, below SW slope of Hamarhø massif, 60 m, August 1988, F. Święs 2512 (KRA); Bellsund, W part of Lognedalen, towards NE from the Logna River, 60 m, August 1988, F. Święs 2511 (KRA); Bellsund, SW part of Lognedalsflya, towards S from the Logna River, 70 m, August 1988, F. Święs 2513 (KRA); Bellsund, SE part of Activekammen, Tomtodden, the bottom of hilltop (538 m), $300 \mathrm{~m}$ from the seacoast, 20 m, August 1988, F. Święs 2519 (H; KRA); Isfjorden, Grönfjorden, Barentsburg, 200 m, June 1982, M. Olech (KRA); Kaffiøyra, the highest marine terrace towards W from the Waldemarbreen glacier, $100 \mathrm{~m}$, July 1997, W. Gugnacka-Fiedor (TRN); Kaffiøyra, Bjørneskanka, lateral moraine of the Dahlbreen glacier, 50 m, July 1997, W. Gugnacka-Fiedor (TRN).

\section{Cladonia verticillata (Hoffm.) Schaer. (Fig. 1C)}

Lich. Helv. Spic. 1 (1): 31 (1823).

Cladonia cervicornis ssp. verticillata (Hoffm.) Ahti

Lichenologist 12: 126 (1980).

According to van Herk and Aptroot (2003), C. verticillata (Hoffm.) Schaer. is a separate species in the light of recent taxonomical status of the Cladonia cervicornis group. These authors proposed to treat the three Dutch taxa of the group at the species level: $C$. cervicornis s. str., C. verticillata (Hoffm.) Schaer. and C. pulvinata (Sandst.) van Herk and Aptroot. The first two species can be distinguished mainly due to different characters of the basal squamules: their colour, shape, size and orientation (van Herk and Aptroot 2003). In addition, $C$. verticillata is characterized by boreo-montane distribution while $C$. cervicornis has rather a Mediterranean and subatlantic type of distribution (Nimis 1993; van Herk and Aptroot 2003). Cladonia verticillata has not been reported from Svalbard until now. Its locality was found on slightly acid soil and it was associated with Cladonia macroceras, C. pocillum, C. pyxidata and the liverwort Gymnomitrion coralloides Nees.

Specimen examined. Spitsbergen: Hornsund, N bottom of Jahnfjellet, 220 m, July 2002, P. Osyczka 311 (KRA).

\section{Cladonia coccifera (L.) Willd. (Fig. 1D)}

Fl. Berol. Prodr. 361 (1787).

After the description of the new species Cladonia borealis S. Stenroos and its separation from C. coccifera group by Stenroos (1989), it turned out that $C$. coccifera s.str. has a more limited worldwide distribution. The distribution map of $C$. coccifera (L.) Willd. presented by Stenroos (1989) did not include any locality in the region of Svalbard. On the other hand, on this map only one locality of $C$. borealis was included. The most important morphological characteristics of $C$. coccifera comprise relatively large size of primary squamules and scaly plates, which appea- 

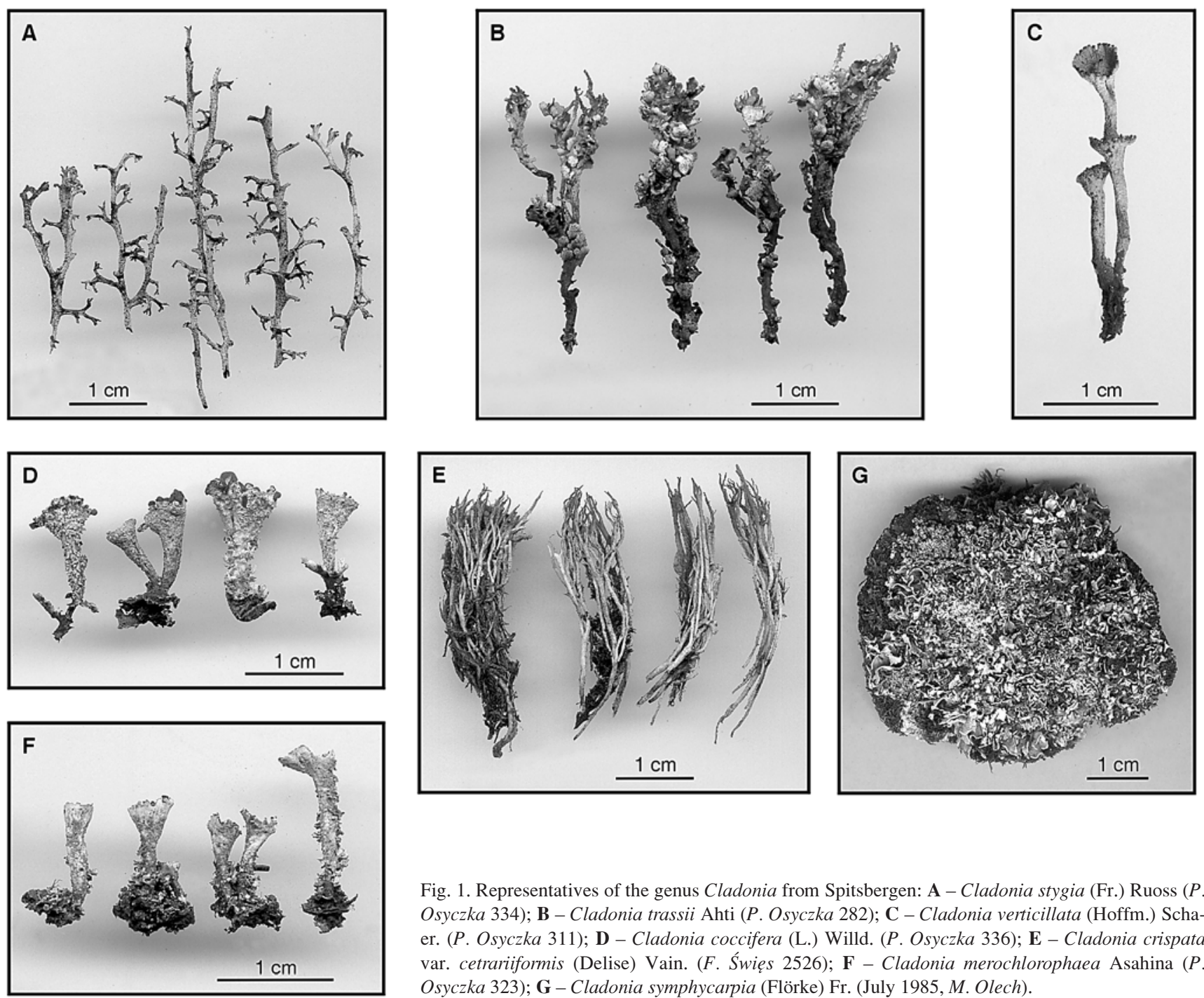

Fig. 1. Representatives of the genus Cladonia from Spitsbergen: A - Cladonia stygia (Fr.) Ruoss (P. Osyczka 334); B - Cladonia trassii Ahti (P. Osyczka 282); C - Cladonia verticillata (Hoffm.) Schaer. (P. Osyczka 311); D - Cladonia coccifera (L.) Willd. (P. Osyczka 336); E - Cladonia crispata var. cetrariiformis (Delise) Vain. (F. Święs 2526); F - Cladonia merochlorophaea Asahina ( $P$. Osyczka 323); G - Cladonia symphycarpia (Flörke) Fr. (July 1985, M. Olech).

ring on the upper surface of the podetia and the interior part of the cup (Stenroos 1989). Chemically, C. coccifera contains zeorin rather than barbatic acid (Stenroos 1989). The presence of zeorin is very helpful to distinguish $C$. coccifera from $C$. borealis, especially in the case of specimens originating from the arctic zone. As a consequence of severe climate the scaly plates typical of $C$. coccifera may be feebly developed or mechanically plucked. In the field the species might be easily overlooked. However, it seems that $C$. coccifera is really rare on Svalbard, contrary to $C$. borealis, which is very common (Osyczka 2003). Localities of $C$. coccifera are situated on denuded mineral soil within a solifluction tongue zone and one of them is connected with bird colonies. It is noteworthy that on Svalbard the taxa belonging to the $C$. coccifera group demonstrate tendency to appear in the neighbourhood of places relevant to nesting birds (Osyczka 2003). Cladonia coccifera was found associated with $C$. macroceras, $C$. mitis, $C$. borealis, Thamnolia vermicularis (Sw.) Schaer. and the bryophyte Tetraplodon mnioides (Hedw.) B.S.G.

Specimens examined. Spitsbergen: Hornsund, W part of Steinvikdalen, near the bank of the Steinvikbekken stream, $120 \mathrm{~m}$, July 2002, P. Osyczka 336 (KRA); Hornsund, W bottom of Jahnfjellet, 230 m, July 2002, P. Osyczka 337 (H; KRA).
Cladonia crispata var. cetrariiformis (Delise) Vain. (Fig. 1E) in Olivier, Rev. Bot. Bull. Mens. 4: 238 (1886).

Cladonia crispata (Ach.) Flot. from Svalbard was reported by Lynge (1938) from Prins Karls Forland but the record was not later confirmed. However, C. crispata var. cetrariiformis was reported from several localities of Spitsbergen at Sørkapp Land by Olech (1990). However, some specimens of this collection belong to C. squamosa Hoffm. Nevertheless, it proves that $C$. crispata var. cetrariformis is quite often present in this part of the Arctic. Besides Sørkapp Land, several more northward localities at Hornsund and Bellsund areas were found. This taxon can be found in the Flavocetraria nivalis-Cladonia rangiferina community and the Racomitrium lanuginosum community as well (Dubiel and Olech 1990).

Selected specimens examined. Spitsbergen: Sørkapp Land, W bottom of søre Sergeijevfjellet, 30 m, July 1985, M. Olech (KRA); Hornsund, NE part of Kvartsittsletta, the bottom of Ceglatoppen, $35 \mathrm{~m}$, July 2002, $P$. Osyczka 313 (KRA); Hornsund, Skjerstranda, near Gangpasset, 20 m, August 1985, M. Olech (KRA); Bellsund, SE part of Dunderdalen, the bottom of Lifjellet, 110 m, August 1992, F. Święs 2524 (KRA); Bellsund, SW part of Lognedalsflya, near Kvitfiskpynten, 5 m, August 1988, F Święs 2528 (KRA); Bellsund, SW part of Vestervagøyra, $40 \mathrm{~m}$, August 1987, F. Święs 2527 (KRA); Bellsund, Dunderdalen, NE slope of Konglemeratfjellet, 95 m, August 1992, F. Święs 2523 (KRA); Bellsund, SW 
part of Relinholmen, 7 m, August 1987, F. Święs 2525 (KRA); Bellsund, SE part of Chamberlinpasset, the slope of hill (575 m), 180 m, July 1988, F. Święs 2526 (KRA); Bellsund, Chamberlindalen, NE part of Vestliknausane, 30 m, July 1987, F. Święs 2522 (H; KRA).

\section{Cladonia merochlorophaea Asahina (Fig. 1F)}

J. Jap. Bot. 16: 713 (1940).

Elvebakk and Tønberg (1992) reported this species as new to Svalbard based on one specimen from Hornsund, previously published by Lynge (1938) as C. grayi, and only one new collection from the Isfjorden area (Colesbukta). However, probably it occurs much more frequent than hitherto reported. Additional localities of $C$. merochloropha$e a$ in Hornsund, Bellsund and at Sørkapp Land were noticed. The species occurred in company of $C$. chlorophaea or $C$. pyxidata and it is probable that $C$. merochlorophaea was often overlooked or confused with these taxa in the past. At Sørkapp Land C. merochlorophaea appeared in the Tetraplodon mnioides community, which is coprophilous (based on material previously published as C. pyxidata; Dubiel and Olech 1990).

Specimens examined. Spitsbergen: Sørkapp Land, the bottom of Nordre Sergeijevfjellet, 50 m, August 1982, M. Olech (KRA); Hornsund, Ralstranda, between Jakobsenpynten and Låkpynten, $20 \mathrm{~m}$, July 2002, $P$. Osyczka 323 (KRA); Hornsund, NE part of Kvartsittsletta, near lake Pikedammen, 50 m, July 2002, P. Osyczka 325 (KRA); Bellsund, SE part of Vestervagøyra, the slope of hill (105 m), 40 m, July 1987, F. Święs 2536 (KRA); Bellsund, SE part of Vestervagøyra, 10 m, July 1987, F. Święs 2535 (KRA).

Cladonia symphycarpia (Flörke) Fr. (Fig. 1G)

Sched. Crit. Lich. Suec. 8-9: 20 (1826).

The species was found on Spitsbergen (Van Keulenfjorden), Amsterdamøya and Nordaustlandet (S. Korsøya, Wargentindalen) and published as C. subcervicornis (Vain.) Kernst. by Lynge (1938). After revision by Ahti the material belongs to $C$. symphycarpia (after Elvebakk and Hertel 1996). The present localities of the species were known only from Sørkapp Land (Olech 1990). Cladonia symphycarpia was also found in several localities in the Bellsund region. The examined specimens have only squamules of the primary thallus and belong to the norstictic strain. They overgrew slightly alkalinous substratum. Climate factors of Svalbard region (e.g. snow cover) may be a cause why primary thallus of the species might be poorly developed or pressed into the soil. Then $C$. symphycarpia could be overlooked or mistakenly determined. In the Bellsund region $C$. symphycarpia appears mostly in the mesophilous type of tundra.

Specimens examined. Spitsbergen: Sørkapp Land, Liddalen, 75 m, July 1985, M. Olech (KRA); Bellsund, NE part of Calypsostranda, the edge of a cliff coast, S side of the Scott River outlet, 20 m, July 1987, F. Święs 2549 (KRA); Bellsund, SW part of Calypsostranda, near moraine of the Renardbreen glacier, 85 m, August 1987, F. Święs 2548 (KRA); Bellsund, NW part of Dunderdalen, the bottom of Dunderfjellet, central part of rangr, $60 \mathrm{~m}$, July 1992, F. Święs 2551 (KRA); Bellsund, NW part of Dunderdalen, S slope of hill $(670 \mathrm{~m}), 160 \mathrm{~m}$, July 1992, F. Świes 2564 (KRA); Bellsund, NW part of Dunderdalen, the bottom of hill (540 m), 65 m, July 1992, F. Święs 2552 (KRA); Bellsund, SE part of Lyellstranda, NE bottom of Wijkanderberget, 120 m, July 1988, F. Święs 2547 (KRA).

\section{ACKNOWLEDGMENTS}

I would like to express my gratitude to all persons from the Institute of Geophysics of the Polish Academy of Scien- ces, Institute of Oceanology of the Polish Academy of Science and Institute of Geology and Mineral Deposits of University of Mining and Metallurgy for help me in organization of my Spitsbergen expediton. I thank Prof. Florian Święs very much for delivery of his reach lichen collection from Bellsund area to our herbarium. I also thank Prof. Maria Olech and Prof. Wanda Gugnacka-Fiedor for access to their lichen collection. I wish to thank Prof. Teuvo Ahti for checking of my determinations of some Cladonia specimens. I appreciate the Governor of Svalbard for permission for my field research in the region of Spitsbergen. Part of this research was supported by the State Committee for Scientific Research (KBN), grant No 3 P04F 05922.

\section{LITERATURE CITED}

AHTI T. 1998. A revision of Cladonia stricta. Folia Cryptog. Estonica 32: 5-8.

AHTI T., HYVÖNEN S. 1985. Cladina stygia, a common overlooked species of reindeer lichen. Ann. Bot. Fenn. 22: 223-229.

BRODO I.M., SHARNOFF S.D., SHARNOFF S. 2001. Lichens of North America. Yale University Press, New Haven and London, pp. 795.

CULBERSON C.F., KRISTINSSON H. 1970. A standardized method for identification of lichen products. J. Chromatogr. 46: 85-93.

DUBIEL E., OLECH M. 1990. Plant communities of NW Sørkapp Land (Spitsbergen). Zesz. Nauk. UJ, Prace Bot. 22: 15-38.

ELVEBAKK A., HERTEL H. 1996. Part 6. Lichens. In: A catalogue of Svalbard plants, fungi, algae, and cyanobacteria. Elvebakk A., Prestrud P. (eds). Norsk Polarinstitutt Skrifter 198: 271-359.

ELVEBAKK A., TØNSBERG T. 1992. Addition to the lichen flora of Svalbard. Graphis Scripta 3: 140-147.

HISDAL V. 1985. Geography of Svalbard. 2nd Edn. Norsk Polarinstitutt, Oslo.

LYNGE B. 1938. Lichens from the west and north coasts of Spitsbergen and the North-East Land collected by numerous expeditions. I. The macrolichenes. Skrifter utgitt av Det Norske Videnskaps-Akademi i Oslo. I. Mat.-Naturv. Klasse. 1938. 6: 1-136.

NIMIS P.L. 1993. The lichens of Italy. An annotated catalogue. Museo Regionale di Scienze Naturali, Monografie XII, Torino, pp. 897.

OLECH M. 1990. Lichens of the NW Sørkapp Land (Spitsbergen). Zesz. Nauk. UJ, Prace Bot. 21: 197-210.

ORANGE A., JAMES P.W., WHITE F.J. 2001. Microchemical methods for the identification of lichens. British Lichen Society, London, pp. 101.

OSYCZKA P. 2003. Gatunki rodzaju Cladonia Hill ex Browne w rejonie Spitsbergenu (Arktyka) - chemotaksonomia i rozmieszczenie. PhD thesis, Department of Polar Research and Documentation, Institute of Botany, Jagiellonian University, Kraków. (in Polish)

RUOSS E., AHTI T. 1989. Systematics on some reindeer lichens (Cladonia subg. Cladina) in the southern hemisphere. Lichenologist 21: 29-44.

STENROOS S. 1989. Taxonomy of the Cladonia coccifera group. 1. Ann. Bot. Fenn. 26: 157-168.

STENROOS S., HYVÖNEN J., MYLLYS L., THELL A., AHTI T. 2002. Phylogeny of the genus Cladonia s. lat. (Cladoniaceae, Ascomycetes) inferred from molecular, morphological, and chemical data. Cladistics 18: 237-278.

VAN HERK C.M., APTROOT A. 2003. A new status for the Western European taxa of the Cladonia cervicornis group. Biblioth. Lichenol. 86: 193-203.

WHITE F.J., JAMES P.W. 1985. New guide to microchemical techniques for the identification of lichen substances. Briti. Lich. Soc. Bull. 57 (suppl.): 1-41. 